\title{
HUBUNGAN PENGETAHUAN IBU HAMIL TENTANG MANFAAT SENAM HAMIL DENGAN TINDAKAN SENAM HAMIL DI KLINIK HJ. MERA MEDAN TAHUN 2018
}

\author{
Evi Lina Rahayu, Debi Novita Siregar* \\ Program Studi D-III Kebidanan Fakultas Keperawatan Dan Kebidanan Universitas Prima Indonesia, \\ Jalan Danau Singkarak, Gg. Madrasah, Medan
}

\begin{abstract}
Abstrak
Senam hamil adalah terapi latihan gerak untuk mempersiapkan ibu hamil, secara fisik atau mental, pada persalinan cepat, aman dan spontan. Mulai dari usia kehamilan 28 minggu s/d saat menjelang persalinan. Tujuan dari penelitian ini untuk mengetahui hubungan pengetahuan ibu hamil tentang manfaat senam hamil dengan tindakan senam hamil di klinik Hj. Mera Medan tahun 2018. Jenis penelitian ini adalah analitik dengan desain penelitian cross sectional dengan besar sampel 36 orang dengan metode pengambilan sampel accidental sampling. Penelitian ini dilakukan pada tanggal 31 Mei 2018 sampai 2 Juni 2018.Instrumen dalam penelitian ini berupa kuesioner yang meliputi data demografi, pernyataan pengetahuan dan pernyataan tindakan senam hamil. Hasil penelitian menunjukkan mayoritas ibu hamil berpengetahuan baik sebanyak 29 orang $(80,6 \%)$ dan yang melakukan tindakan senam hamil sebanyak 19 orang (52,8 \%). Setelah di lakukan uji fisher exact disimpulkan ada hubungan yang signifikan antara pengetahuan ibu hamil tentang manfaat senam hamil dengan tindakan senam hamil karena p value $<0.05$ atau $(0.002<0.05)$. Diharapkan tenaga kesehatan lebih meningkatkan penyuluhan-penyuluhan yang dilakukan di seluruh klinik sehingga ibu hamil memiliki pengetahuan dan pemahaman tentang manfaat senam hamil dan ibu hamil mau melakukan senam hamil.
\end{abstract}

Kata kunci :

\section{PENDAHULUAN}

Menjadi seorang ibu merupakan kodrat seorang perempuan. Hamil, melahirkan, dan mempunyai anak juga hal yang sangat dinanti-nantikan oleh perempuan yang telah hidup berkeluarga. Kehamilan merupakan sebuah proses alamiah yang ditunggu-tunggu oleh sebagian besar kaum wanita. Ibu yang sedang mengalami kehamilan dan ingin melahirkan secara normal, dituntut tidak hanya harus siap secara fisik, tetapi juga harus siap secara mental (Martalisa \& Budisetyani, 2013).

Kehamilan dan persalinan merupakan suatu proses yang alami dan menimbulkan rasa sakit. Namun banyak wanita yang merasakan sakit tersebut lebih parah dari seharusnya karena banyak dipengaruhi oleh rasa panik dan stres. Hal ini disebut fear-tension-pain concept (takut-tegang-sakit), dimana rasa takut menimbulkan ketegangan atau kepanikan yang menyebabkan otot menjadi kaku dan akhirnya menyebabkan rasa sakit (Larasati, 2012).

Keberhasilan sebuah proses persalinan sangat di pengaruhi oleh kondisi fisik ibu dan bayi, kondisi psikis maupun penolong yang membantu proses persalinan. Proses persalinan pada ibu bersalin normal berlangsung dalam waktu kurang dari 24 jam, dimana terbagi dalam empat kala. Kala I pada fase laten berlangsung selama delapan jam dan fase aktif berlangsung selama tujuh jam. Persalinan kala II biasanya berlangsung dua jam pada primi dan satu jam pada multigravida, kala III berlangsung kurang dari 30 menit sedangkan kala IV dimulai dari saat lahirnya plasenta sampai dua jam pertama post partum (Rahmawati, dkk, 2016).

Lamanya proses persalinan dapat dipengaruhi oleh tiga hal yaitu tenaga, jalan lahir dan janin. Sampai saat ini yang dapat dikendalikan adalah masalah tenaga atau power, yaitu ditingkatkan dengan senam hamil. Senam atau latihan selama kehamilan memberikan efek positif terhadap pembukaan serviks dan aktivitas uterus yang terkoordinasi saat persalinan, juga ditemukan secara bermakna onset persalinan yang lebih awal dan lama persalinan yang lebih singkat dibandingkan dengan yang tidak melanjutkan senam hamil, senam hamil dapat membantu persalinan sehingga ibu dapat melahirkan tanpa kesulitan, serta menjaga ibu dan bayi sehat setelah melahirkan (Rahmawati, dkk, 2016).

Senam hamil adalah program kebugaran yang diperuntukkan bagi ibu hamil sehingga memiliki prinsipprinsip gerakan khusus yang disesuaikan dengan kondisi ibu hamil. Latihan senam hamil dirancang khusus untuk menyehatkan dan membugarkan ibu hamil, mengurangi keluhan yang timbul selama kehamilan serta mempersiapkan fisik dan psikis ibu menghadapi persalinan (Nurhudhariani, dkk, 2015). 
Jumlah ibu hamil di Indonesia terus mengalami peningkatan dari tahun ke tahun. Berdasarkan data BKKBN diketahui dari tahun 2007 sebanyak 5.333.611 orang, tahun 2008 sebanyak 5.240.451 orang, tahun 2009 sebanyak 5.182.927 orang, tahun 2010 sebanyak 5.191.116 orang dan tahun 2011 sebanyak 5.192.427 orang, dan pada tahun 2014 sebanyak 5.290.235 orang (Rate, 2016).

Derajat kesehatan sangat ditentukan oleh kesehatan ibu dan anak. World Health Organization (WHO) memperkirakan di seluruh dunia setiap tahunnya lebih dari 585.000 meninggal saat hamil atau bersalin (Kepmenkes, 2012). Hasil penelusuran Departemen Kesehatan tahun 2011, Angka Kematian Ibu (AKI) di Indonesia adalah 214 per 100.000 kelahiran hidup sedangkan AKI Propinsi Jawa Tengah tahun 2012 berdasarkan hasil Survey Kesehatan Daerah sebesar 116 per 100.000 kelahiran hidup. Depkes sedang menggalakkan program Making Pregnancy Saver (MPS) dengan program antara lain Program Perencanaan Persalinan dan Pencegahan Komplikasi (P4K) (Depkes, 2010).

Angka kematian maternal dan perinatal di Indonesia masih cukup tinggi. Salah satu penyebab kematian maternal dan perinatal di Indonesia dan negara negara berkembang lainnya adalah akibat partus lama. Menurut SDKI tahun 2003 penyebab kematian ibu, yaitu karena komplikasi persalinan (45\%), retensio plasenta (21\%), robekan jalan lahir (19 \%), partus lama (11 \%), perdarahan dan pre eklamsi masing-masing (10 \%), komplikasi selama nifas (5 \%) dan demam infeksi (4\%) (Elizawarda, 2016).

Berdasarkan jurnal dari Elizawarda yang melakukan penelitian tentang senam hamil bahwa hasil penelitian yang di dapat dari 36 responden, mayoritas berpengetahuan baik dan bersikap positif yaitu 23 responden (88,5 \%) sedangkan responden yang berpengetahuan kurang dan bersikap positif sebanyak 4 responden (40,0 \%). Pengetahuan ini diperoleh dengan cara baru atau modern yaitu mengadakan pengamatan langsung terhadap gejala- gejala alam atau masyarakat kemudian hasil pengamatan tersebut dikumpulkan, diklasifikasikan, dan akhirnya pengamatan tersebut diambil kesimpulan umumnya faktor-faktor yang mempengaruhi pengetahuan adalah umur, pendidikan, pekerjaan, sumber informasi , dan hasil interaksi dengan lingkungan (Elizawarda, 2016).

Survey pendahuluan di klinik Hj. Mera Medan pada tanggal 14 sampai tanggal 16 Januari 2018 terdapat 8 orang ibu hamil yang datang ke klinik Hj.Mera yang memeriksakan kehamilannya. Berdasarkan hasil wawancara sementara peneliti menemukan ada 5 orang diantaranya yang kurang mengetahui dan belum pernah melakukan senam hamil. Berdasarkan hasil survey yang dilakukakn peneliti, maka peneliti tertarik untuk meneliti masalah senam hamil terutama mengenai “ Hubungan pengetahuan ibu hamil tentang manfaat senam hamil dengan tindakan senam hamil “.

\section{Tujuan Penelitian}

Tujuan umum dalam penelitian ini untuk mengetahui hubungan pengetahuan ibu hamil tentang manfaat senam hamil dengan tindakan senam hamil di Klinik Hj. Mera Medan tahun 2018.

\section{Manfaat Penelitian}

1. Penelitian ini digunakan sebagai masukan dan informasi bagi lingkungan serta dapat menambah pengetahuan dan wawasan sehingga dapat meningkatkan pengetahuan ibu hamil tentang manfaat senam hamil.

2. Semua dijadikan sebagai bahan acuan referensi bagi mahasiswa Fakultas Keperawatan dan Kebidanan Universitas Prima Indonesia Medan serta sebagai bahan acuan di perpustakaan untuk penelitian selanjutnya dan dapat berguna untuk menambah wawasan dan pengetahuan pembaca masalah pengetahuan ibu hamil tentang manfaat senam hamil.

3. Penelitian ini dapat digunakan sebagai bahan informasi untuk pengetahuan ibu hamil tentang manfaat senam hamil.

\section{Kerangka Konsep}

Kerangka konsep penelitiaan adalah suatu hubungan atau kaitan antara konsep terhadap konsep yang lain dari masalah yang ingin diteliti. Konsep merupakan suatu abstrak atau dapat dikatakan penyaringan antara peristiwa yang dibentuk dengan menyimpulkan suatu pengertian, konsep tersebut dijabarkan menjadi dua yakni :

1. Variabel independent (bebas) yaitu variabel yang sifatnya mempengaruhi.

2. Variabel dependent (terikat) yaitu variabel yang sifatnya terpengaruhi.

\section{Variabel Dependen}

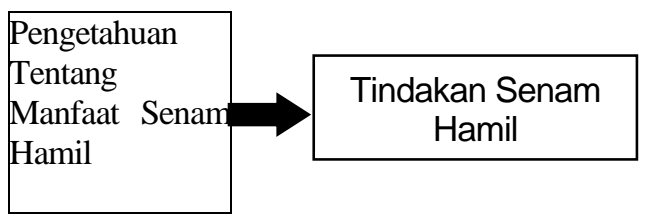

\section{Hipotesis}

Ada hubungan pengetahuan ibu hamil tentang manfaat senam hamil dengan tindakan senam hamil di Klinik HJ. Mera Medan Tahun 2018.

\section{METODE PENELITIAN}

\section{Jenis Dan Desain Penelitian}

Jenis yang di gunakan dalam penelitian ini adalah analitik dengan desain penelitian cross sectional yaitu pendekatan , pengumpulan data diteliti sekaligus pada suatu saat (Notoatmodjo 2012). Penelitian ini bertujuan untuk mengetahui hubungan pengetahuan ibu hamil tentang manfaat senam hamil dengan tindakan senam hamil di Klinik Hj. Mera Medan Tahun 2018. 


\section{Populasi Dan Sampel Penelitian}

Populasi dalam penelitian ini adalah semua ibu hamil yang datang di Klinik Hj. Mera Medan pada bulan Januari sampai dengan Maret berjumlah 70 orang.

Sampel adalah sebagian atau wakil populasi yang diteliti. Sampel dalam penelitian ini adalah accidental sampling yaitu cara pengambilan sampel yang di lakukan dengan kebetulan bertemu untuk melakukan senam hamil di Klinik Hj. Mera sebagai objek penelitian dengan jumlah sampel 36 orang (Notoatmodjo, 2012).

\section{HASIL DAN PEMBAHASAN}

\section{Hasil Penelitian}

\subsection{Analisis Univariat}

\section{A. Analisa Univariat}

Hasil penelitian tentang hubungan pengetahuan ibu hamil tentang manfaat senam hamil dengan tindakan senam hamil di Klinik Hj. Mera Medan Tahun 2018.

Tabel 4.1 Distribusi Frekuensi Pengetahuan Ibu Hamil Tentang Manfaat Senam Hamil Di Klinik Hj. Mera Medan Tahun 2018

\begin{tabular}{llll}
\hline No & Variabel & Jumlah (n) & $\begin{array}{l}\text { Persentase } \\
\text { (\%) }\end{array}$ \\
\hline 1 & Pengetahuan & & \\
& a. Baik & 29 & 80,6 \\
& b. Kurang & 7 & 19,4 \\
\hline & Total & 36 & 100 \\
\hline
\end{tabular}

Berdasarkan tabel 4.1 di atas diketahui bahwa dari 36 responden mayoritas responden pengetahuan baik yaitu sebanyak 29 orang (80,6 \%) dan minoritas pengetahuan kurang sebanyak 7 orang (19,4\%).

Tabel 4.2 Distribusi Frekuensi Tindakan Senam Hamil Di Klinik Hj. Mera Medan Tahun 2018

\begin{tabular}{llll}
\hline No & Variabel & Jumlah (n) & $\begin{array}{l}\text { Persentase } \\
\text { (\%) }\end{array}$ \\
\hline 1 & Tindakan & & \\
& a. Dilakukan & 19 & 52,8 \\
& b. Tidak & 17 & 47,2 \\
& dilakukan & & \\
\hline & Total & 36 & 100 \\
\hline
\end{tabular}

Berdasarkan tabel 4.2 tindakan senam hamil, diketahui bahwa 36 responden mayoritas melakukan tindakan senam hamil yaitu sebanyak 19 orang (52,8 \%) dan minoritas yang tidak melakukan senam hamil yaitu sebanyak 17 orang (47,2 \%).

\section{Analisis Bivariat}

Tabel 4.3 Hubungan Pengetahuan Ibu Hamil Tentang Manfaat Senam Hamil Dengan Tindakan Senam Hamil Di Klinik Hj. Mera Medan Tahun 2018

\begin{tabular}{|c|c|c|c|c|c|c|c|}
\hline \multirow{3}{*}{$\begin{array}{c}\text { Variabel } \\
\text { Pengetahuan }\end{array}$} & \multicolumn{4}{|c|}{ Tindakan } & \multirow{2}{*}{\multicolumn{2}{|c|}{ Total }} & \multirow{3}{*}{ P Value } \\
\hline & \multicolumn{4}{|c|}{ Dilakukan $\begin{array}{c}\text { Tidak } \\
\text { dilakukan }\end{array}$} & & & \\
\hline & $\mathbf{n}$ & $\%$ & $\mathbf{n}$ & $\%$ & $\mathbf{n}$ & $\%$ & \\
\hline Baik & 19 & 65,5 & 10 & 34,5 & 29 & 100 & 0.002 \\
\hline Kurang & 0 & 0 & 7 & 100 & 7 & 100 & \\
\hline
\end{tabular}

Berdasarkan tabel 4.2, responden berpengetahuan baik sebanyak 29 orang, mayoritas melakukan tindakan senam hamil sebanyak 19 orang (65,5 \%) dan minoritas tidak melakukan senam hamil sebanyak 10 orang (34,5\%). Dari responden berpengetahuan kurang sebanyak 7 orang, mayoritas semua responden tidak melakukan tindakan senam hamil.

Berdasarkan hasil uji exact fisher dengan taraf signifikan 0,05 maka diperoleh $p$ value 0.002 yang artinya Ho ditolak dan Ha diterima maka dapat disimpulkan adanya hubungan yang signifikan antara pengetahuan ibu hamil dengan tindakan senam hamil di Klinik Hj. Mera Medan Tahun 2018.

\section{Pembahasan}

Hasil penelitian yang dilakukan mengenai hubungan pengetahuan ibu hamil tentang manfaat senam hamil dengan tindakan senam hamil di Klinik Hj. Mera Medan Tahun 2018.

Berdasarkan tabel 4.1 dari 36 responden ibu hamil yang diteliti di Klinik Hj. Mera Medan tahun 2018 mayoritas berpengetahuan baik sebanyak 29 orang $(80,6 \%)$ dan minoritas berpengetahuan kurang sebanyak 7 orang $(19,4 \%)$.

Hal ini sesuai dengan penelitian sari (2014) tentang hubungan pengetahuan ibu hamil dengan sikap ibu hamil di RS. Elisabet Medan yang menunjukkan mayoritas responden berpengetahuan baik sebanyak 39 orang (72,2 \%) dan minoritas berpengetahuan kurang sebanyak 15 orang (27,8 \%). Melihat kenyataan tersebut dapat diartikan bahwa pengetahuan responden tentang manfaat senam hamil sudah mempunyai pengetahuan baik.

Menurut Notoatmodjo 2012, pengetahuan dipengaruhi oleh faktor pendidikan formal. Pengetahuan sangat erat hubungannya dengan pendidikan, dimana diharapkan bahwa dengan pendidikan yang tinggi maka orang tersebut akan semakin luas pula pengetahuannya. Akan tetapi perlu ditekankan, bukan berarti seseorang yang berpendidikan rendah mutlak berpengetahuan rendah, pengetahuan tidak mutlak diperoleh oleh pendidikan formal saja, akan tetapi dapat diperoleh melalui pendidikan non formal.

Pendidikan berarti bimbingan yang diberikan seseorang kepada orang lain agar memahami suatu hal. Pendidikan diperlukan untuk mendapat informasi. 
Menurut YB Mantra yang di kutip Notoadmojo (2003), pendidikan dapat mempengaruhi seseorang termasuk juga perilaku seseorang akan pola hidup terutama dalam memotivasi untuk sikap berperan serta dalam pembangunan, pada umumnya makin tinggi pendidikan seseorang makin mudah menerima informasi (wawan, 2017).

Berdasarkan tabel 4.1 di atas diketahui bahwa dari 36 responden terdapat 29 orang (80,6 \%) berpengetahuan baik karena mereka berpendidikan tinggi, sering mendengarkan penyuluhan yang dilakukan oleh petugas kesehatan tentang senam hamil dan memiliki alat komunikasi yang canggih sehingga mampu mengakses informasi secara baik, dan 7 orang (19,4\%) berpengetahuan kurang karena mereka rata-rata rendah dalam pendidikan dan teknologi.

Berdasarkan tabel 4.1 dari 36 responden ibu hamil yang diteliti di Klinik Hj. ,Mera Medan tahun 2018 tentang senam hamil mayoritas melakukan tindakan senam hamil yaitu sebanyak 19 orang $(52,8$ \%) dan minoritas yang tidak melakukan senam hamil yaitu sebanyak 17 orang (47,2 \%).

Hal ini juga sesuai dengan penelitian Sari (2014) tentang hubungan pengetahuan dengan sikap ibu hamil terhadap senam hamil di RS. Elisabet Medan yang menunjukkan mayoritas responden bersikap positif sebanyak 43 orang $(79,7 \%)$ dan minoritas bersikap negatif sebanyak 11 orang (20,3\%).

Hal ini sesuai dengan pendapat Mawan (2011) pengetahuan merupakan domain yang sangat penting untuk terbentuknya tindakan seseorang (ovent behavior). Dari pengalaman dan penelitian ternyata perilaku yang didasari oleh pengetahuan akan lebih langgeng daripada perilaku yang tidak didasari oleh pengetahuan.

Sehingga diketahui adanya responden yang melakukan tindakan senam hamil hal ini disebabkan karena kecendrungan dan kebiasaan dari diri mereka sendiri (faktor internal) yaitu mampu mengaplikasikan pengetahuan yang mereka miliki dalam situasi dan kondisi yang sebenarnya, dan mereka tahu bahwa senam hamil itu bermanfaat.

Berdasarkan hasil uji exact fisher dengan taraf signifikan 0,05 maka diperoleh hasil p value 0,002, yang artinya Ho ditolak dan Ha diterima maka terdapat hubungan pengetahuan ibu hamil tentang manfaat senam hamil dengan tindakan senam hamil.

Berdasarkan hasil yang diperoleh, responden berpengetahuan baik sebanyak 29 orang (80,6 \%), mayoritas melakukan tindakan senam hamil sebanyak 19 orang (65,5 \%) dan minoritas tidak melakukan senam hamil sebanyak 10 orang (34,5 \%). Dari responden berpengetahuan kurang sebanyak 7 orang $(19,4 \%)$, mayoritas semua responden tidak melakukan tindakan senam hamil.

Pernyataan ini sesuai dengan penelitian yang dilakukan oleh Sari Tahun 2014 di RS. Santa Elisabet Medan tentang judul hubungan pengetahuan dengan sikap ibu hamil terhadap senam hamil di RS. Elisabet Medan tahun 2014 diperoleh hasil ada hubungan pengetahuan dengan sikap ibu hamil terhadap senam hamil di RS. Santa Elisabet Medan Tahun 2014.

Menurut asumsi peneliti, seseorang yang memiliki pengetahuan tinggi akan lebih memahami tentang senam hamil serta akan melakukan senam hamil. Dengan kata lain yang melakukan senam hamil banyak di temukan pada responden yang berpengetahuan baik dibandingkan dengan yang berpengetahuan kurang, karena yang berpengetahuan baik akan melakukan hal-hal yang dirasakan bermanfaat baginya.

\section{SIMPULAN DAN SARAN}

\section{A. Simpulan}

1. Mayoritas ibu hamil berpengetahuan baik tentang manfaat senam hamil di Klinik $\mathrm{Hj}$. Mera Medan Tahun 2018 sebanyak 29 orang (80,6 \%)

2. Mayoritas ibu hamil melakukan tindakan senam hamil sebanyak 19 orang (65,5 \%)

3. Ada hubungan yang signifikan antara pengetahuan ibu hamil tentang manfaat senam hamil denga tindakan senam hamil di Klinik Hj. Mera Medan Tahun 2018.

\section{B. Saran}

1. Ibu hamil diharapkan mampu memperoleh informasi mengenai manfaat senam hamil dan melakukan tindakan senam hamil untuk mempermudah proses persalinan dan menghilangkan stress serta rasa takut yang mengiringi proses persalinan dan digantikan dengan rasa rileks, tenang, dan percaya diri.

2. Petugas kesehatan di Klinik $\mathrm{Hj}$. Mera diharapkan untuk memberikan konseling dan meningkatkan penyuluhan-penyuluhan kepada ibu hamil agar ibu memiliki pengetahuan tentang manfaat senam hamil dan ibu hamil mau melakukan senam hamil yang bertujuan untuk mengurangi rasa nyeri saat persalinan dan memperlancar proses persalinan.

3. Diharapkan dimasa yang akan datang dilakukan penelitian lebih lanjut berdasarkan faktor lainnya, variabel yang berbeda, jumlah sampel yang lebih banyak, tempat yang berbeda, dan tetap berhubungan dengan senam hamil dan peneliti dapat mengurangi rasa cemas dan takut pada ibu hamil pada masa kehamilan dan begitu juga pada saat menjelang persalinan.

\section{DAFTAR PUSTAKA}

Elizawarda. 2016. Hubungan Pengetahuan Dengan Sikap Ibu Hamil Terhadap Senam Hamil Di Desa Sei Litur Tasik Kecamatan Sawit Seberang Kabupaten Langkat. http://pannmed.poltekkesmedan.ac.id/files/2016/Vol.11_elizawarda.pdf. Diakses pada tanggal 04 desember 2017. 
Intyaswati, Albina Handriana Ganggu. 2017. Gambaran Tingkat Pengetahuan Ibu Hamil Tentang Senam Hamil Di Bkia Rumah Sakit William Booth Surabaya.

http://ejournal.stikeswilliambooth.ac.id/index.php/Ke b/article/view/151. Di akses pada tanggal 06 Desember 2017.

Maryunani,Atika \& Yetty Sukaryati. 2017. Senam Hamil Senam Nifas Dan Terapi Musik. TIM, Jakarta

Mubarak,Wahit Iqbal. 2012. Promosi Kesehatan Untuk Kebidanan. Salemba Medika, Jakarta

Notoatmodjo,Soekidjo. 2012. Metodologi Penelitian Kesehatan. Rineka Cipta, Jakarta

Sari,Ermala. 2014. Hubungan Pengetahuan Dengan Sikap Ibu Hamil Terhadap Senam Hamil Di Rumah Sakit Elisabet Medan Tahun 2014. https://anzdoc.com/hubungan-pengetahuan-dengansikap-ibu-hamil-terhadap-senam-h.html. Di akses pada tanggal 04 desember 2017.

Suratiah,dkk. 2013. Pengetahuan Ibu Hamil Tentang Senam Hamil. $\quad \underline{\text { http://poltekkes- }}$ denpasar.ac.id/files/JURNAL\%20GEMA\%20KEPE RAWATAN/JUNI\%202014/Suratiah,\%20dkk.pdf. Di akses pada tanggal 03 desember 2017.
Wawan A. \& Dewi M. 2017. Teori \& Pengukuran Pengetahuan, Sikap, dan Perilaku Manusia. Nuha Medika, Yogyakarta

Wibowo, 2012. Pengaruh Keikutsertaan Senam Hamil Terhadap Kecemasan Primigravida Trimester Ketiga Dalam Menghadapi Persalinan. http://www.journal.unair.ac.id/filerPDF/3.Inka\%20P uty\%20Larasati-

Arief\%20Wibowo\%20(Volume\%201\%20nomor\%2 01).pdf. Di akses pada tanggal 07 Desember 2017.

Widianti,Anggriyana Tri \& Atikah Proverawati. 2017. Senam Kesehatan. Nuha Medika, Yogyakarta 